\title{
An Introduction to Thermogeology: - Ground Source Heating and Cooling
}

Anmeldt af geolog cand.scient. Inga Sørensen, VIA University College i Horsens

Andetsteds i dette nummer kan man læse om de aktuelle planer om jordvarmeboringer i Horsens. Skulle nogle læsere have fået lyst til at læse mere om dette spændende emne, var det måske en idé at anskaffe bogen, som anmeldes hér!

Bogen beskæftiger sig med de ressourcer af stabil varme, der findes i de øvre jordlag - og det er også aktuelt, selvom man ikke bor på Island eller andre vulkanske områder. Der er således altid en stabil varme at indvinde fra jord og grundvand i en normal "brøndborerdybde" - dvs. max. et par hundrede meter. Og her er der megen energi at hente - et virkeligt seriøst alternativ til olie og gas, hvis man ellers forstår processerne i disse dybder og kender noget til den nødvendige teknik for at hente energien op til overfladen.

\section{Pædagogisk og velskrevet}

Dette kendskab har bogens forfatter David Banks i meget høj grad - og han har også en fremragende evne til at formidle denne viden. Med stor pædagogisk indsigt sammenlignes termodynamikkens begreber med almindelige fænomener, som vi alle kender fra dagligdagen. Relevante historiske beretninger er med til at bygge forståelsen op omkring jordvarmens natur, og hvordan

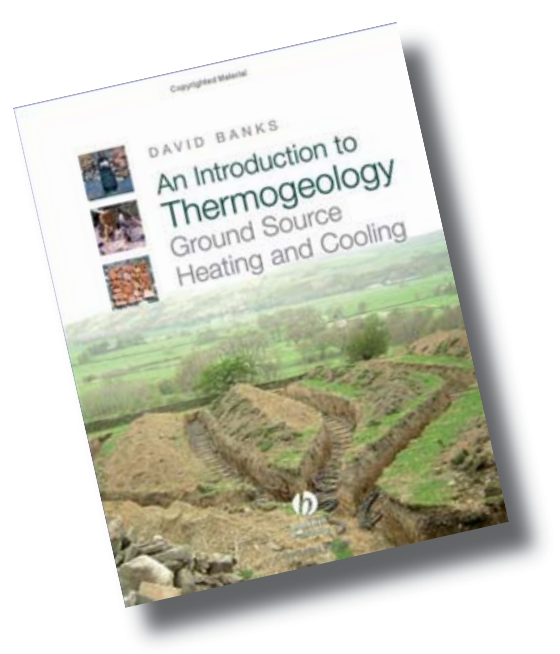

den"-forklaringer er med til at formidle det teoretiske indhold på en spændende måde. Overskuelige bokse med komprimeret teori giver en god struktur i den inspirerende tekst, hvor der spilles på alle naturvidenskabens strenge.

Principperne i varmepumpen forklares således meget grundigt ved bl.a. at bruge køleskabet som eksempel på et varmeapparat i køkkenet - et varmeapparat der foruden strøm fra el-nettet også fodres med energi fra afkøling af den mad, vi sætter ind i køleskabet.

\section{Gammeldags dyder i højsædet}

Der er ingen farveillustrationer i bogen men de savnes ikke, fordi de sorthvide fotos og stregtegninger på udmærket vis supplerer teksten. Og så har bogen alle de gammeldags dyder, en god lærebog skal have - stikordsregister, mange litteraturhenvisninger, ordforklaringer, symboloversigter og oversigt over anvendte enheder - foruden orienterende krydshenvisninger mellem de forskellige afsnit af bogen.

Det er sjældent, at man har brug for de meget store superlativer, når man skal omtale en bog, men i tilfældet her, er det næsten ikke til at få armene ned. Denne bog bør blive en bibel for alle dem, der gerne vil have indsigt i jordvarmens natur, og hvordan vi i praksis kan udnytte den.

David Banks bog er udgivet af forlaget Blackwell i 2008. Prisen er relativt høj-90 euro uden moms - men den er alle pengene vœrd. ISBN: 978-1-4061-7061-1 